\title{
Impacts of glacier recession and declining meltwater on mountain societies
}

Carey, Mark; Molden, Olivia C.; Rasmussen, Mattias Borg; Jackson, M.; Nolin, Anne W.; Mark, Bryan G.

Published in:

Annals of the Association of American Geographers

DOI:

10.1080/24694452.2016.1243039

Publication date:

2017

Document version

Peer reviewed version

Citation for published version (APA):

Carey, M., Molden, O. C., Rasmussen, M. B., Jackson, M., Nolin, A. W., \& Mark, B. G. (2017). Impacts of glacier recession and declining meltwater on mountain societies. Annals of the Association of American Geographers, 107(2), 350-359. https://doi.org/10.1080/24694452.2016.1243039 
This is the author's postprint version of an article in Annals of the Association of American Geographers, vol. 107, no. 2, pp. 350-359. The authoritative version can be found here: https://doi.org/10.1080/24694452.2016.1243039

The present research benefitted from funding from the European Research Council (ERC). ERC Grant: State Formation Through the Local Production of Property and Citizenship (Ares

(2015)2785650 - ERC-2014-AdG - 662770-Local State).

\section{Impacts of Glacier Recession and Declining Meltwater on Mountain Societies}

Mark Carey, ${ }^{*}$ Olivia C. Molden, ${ }^{\mathrm{y}}$ Mattias Borg Rasmussen, ${ }^{\mathrm{z}}$ M Jackson, ${ }^{\mathrm{y}}$ Anne W. Nolin, ${ }^{\mathrm{x}}$ and Bryan G. Mark ${ }^{\mathrm{v}}$

*Robert D. Clark Honors College and Environmental Studies Program, University of Oregon

${ }^{y}$ Department of Geography, University of Oregon

${ }^{\mathrm{z}}$ Department of Food and Resource Economics, University of Copenhagen

${ }^{\mathrm{x}}$ College of Earth, Ocean, and Atmospheric Sciences, Oregon State University

${ }^{\mathrm{v}}$ Department of Geography and Byrd Polar and Climate Research Center, The Ohio State University

Glacierized mountains are often referred to as our world's water towers because glaciers both store water over time and regulate seasonal stream flow, releasing runoff during dry seasons when societies most need water. Ice loss thus has the potential to affect human societies in diverse ways, including irrigation, agriculture, hydropower, potable water, livelihoods, recreation, spirituality, and demography. Unfortunately, research focusing on the human impacts of glacier runoff variability in mountain regions remains limited, and studies often rely on assumptions rather than concrete evidence about the effects of shrinking glaciers on mountain hydrology and societies. This article provides a systematic review of international research on human impacts of glacier meltwater variability in mountain ranges worldwide, including the Andes, Alps, greater Himalayan region, Cascades, and Alaska. It identifies four main areas of existing research: (1) socioeconomic impacts; (2) hydropower; (3) agriculture, irrigation, and food security; and (4) cultural impacts. The article also suggests paths forward for social sciences, humanities, and natural sciences research that could more accurately detect and attribute glacier runoff and human impacts, grapple with complex and intersecting spatial and temporal scales, and implement transdisciplinary research approaches to study glacier runoff. The objective is ultimately to redefine and reorient the glacier-water problem around human societies rather than simply around ice and climate. By systematically evaluating human impacts in different mountain regions, the article strives to stimulate cross-regional thinking and 
inspire new studies on glaciers, hydrology, risk, adaptation, and human-environment interactions in mountain regions.

Key Words: climate change impacts, glacier runoff variability, glacier-society interactions, hydrosocial cycle, water sustainability.

Glacier retreat generates far-reaching concerns about water supplies for communities in and around the world's glacierized mountains (Intergovernmental Panel on Climate Change 2014). Despite the possible human impacts from shrinking glaciers, few studies focus primarily on the people and societies in glacierized watersheds. There is thus an urgent need to understand the human impacts of glacier runoff variability in mountain regions - not only for local communities, policy makers, and social science and humanities researchers who focus on human societies but also for natural scientists studying glaciers. Natural scientists frequently frame and conclude their scientific publications with claims about the hydrologic effects of glacier change on downstream societies, often making assertions about human impacts that transcend the scope of the scientific research. Bold impact statements also appear in the media, with The New York Times, for example, writing that "the 46,000 glaciers of the Third Pole [greater Himalayan] region help sustain 1.5 billion people in 10 countries. ... Scattered across nearly two million square miles, these glaciers are receding at an everquickening pace, producing a rise in levels of rivers and lakes in the short term and threatening Asia's water supply in the long run" (Wong 2015).

Such accounts - and academic research as well (National Academy of Sciences 2012) — usually do not explain key issues, though. These include which portion of the population would be influenced, how the number of affected people was determined; when people would be affected; how much glacier runoff is truly accessed for human water use; and what other factors-such as water rights, hydropower development, social conflicts, or agricultural practices - also affect water supplies and management in glacier-fed watersheds. Research on glacier runoff impacts might overemphasize the role of ice, hold human societies static in hydrologic models, not acknowledge social drivers of change, or not differentiate among biophysical and societal forces of hydrologic transformation in glacier-fed watersheds.

Most glacier runoff studies divorce water supply (the hydrological dimensions of water) from water access and allocation (the social dimensions of water management) - despite existing literature on social- ecological systems (Folke 2006), the hydrosocial cycle (Swyngedouw 2009), sociohydrology (Sivapalan, Savenije, and Bl€oschl 2012), and hydrosocial approaches to glacierized watersheds (N€usser, Schmidt, and Dame 2012; Carey et al. 2014). The common tendency is to identify glacier loss and then assume inevitable negative downstream human impacts or social conflicts over water, which is actually a form of environmental determinism (Hulme 2011) and the construction of "apocalyptic imaginaries" (Swyngedouw 2010). Human forces in mountain regions-from tourism and demographic changes to cultural beliefs, race relations, and government laws - are rarely identified and analyzed in glacier runoff research. Instead, the issue of mountain water is reduced to a problem of climate change and glacier shrinkage, an environmental problem driven by global 
temperatures and the shifting mass balance of glaciers that conceals other drivers of water scarcity (human beings) and thus fails to point toward effective adaptation strategies.

This article evaluates and synthesizes literature examining societal impacts of glacier runoff variability in mountain regions worldwide, simultaneously charting new paths forward to refine and reorient mountain research. Five representative regions serve as case studies for this analysis: the Andes, Alps, greater Himalayan region, North Cascades, and Alaska. The article is organized by impacts rather than by specific mountain range or political boundary. Four impacts predominate in the existing literature: (1) socioeconomic impacts; (2) hydropower; (3) irrigation, agriculture, and food security; and (4) cultural aspects. After synthesizing these societal impacts, three directions for future research are discussed: detection and attribution of glacier runoff impacts; consideration of intersecting spatial and temporal scales; and transdisciplinary research to redefine runoff.

\section{Methods}

Research involved a systematic review of existing literature on the societal impacts of glacier runoff variability in the five case study regions, following principles outlined for literature reviews in the social sciences (e.g., Petticrew and Roberts 2006; Rodela 2011). Systematic reviews are essential to digest large and disparate literatures, identify gaps in knowledge, and discover areas of uncertainty in scholarship. They also "flag up areas where spurious certainty abounds. These are areas where we think we know more than we do, but where in reality there is little convincing evidence to support our beliefs" (Petticrew and Roberts 2006, 2).

This systematic review was guided by this overarching research question: What knowledge exists within the published literature regarding the nature and scope of societal impacts of glacier runoff variability? The authors conducted searches for publications published from 1980 to November 2015 using Web of Science, Google Scholar, and Science Direct. Search terms were used for all fields (title, abstract, keywords, full text), such as "glac* runoff," "glacial discharge society," or "glacier water irrigation"- and included mountain ranges (e.g., Cascades), geographic regions (e.g., Himalaya), and mountain and glacier names (e.g., Huascaran). Database filters were used to narrow results to the social sciences and humanities when possible. Publications were included if they (1) addressed societal impacts of glacier runoff variability in a substantive way and (2) examined water flow or hydrological resources from glaciers or in glacier-fed watersheds. The review excluded nonpeer-reviewed publications, media articles, organization reports, theses and dissertations, and gray literature. Natural science publications were excluded when they lacked a human component or did not focus on glacier runoff. Glacial lake outburst floods (GLOFs) are a form of hydrologic variability in glacier-fed watersheds, but they were excluded from this review because they do not necessarily affect water use and are influenced more by moraine and ice dam stability, among other factors, than glacier runoff variability.

More than 500 publications were initially identified (approximately 200 for the Andean region, 200 for the Alps, 120 for the greater Himalayan region, and 50 for the Cascades and Alaska), but only a subset (one quarter to one third) focused on human dynamics of glacier meltwater. This study analyzed the smaller humanfocused subset. Coverage was uneven within regions; for example, in the 
Andes, Peru's Cordillera Blanca has disproportionately high coverage compared with Bolivia, Ecuador, or Patagonia. Analysis also focused on populations affected, geographical scale studied, time range covered, evidence provided, topics studied, methods used, conclusions reached, and other trends. Results showed existing research concentrated in four main categories: socioeconomics, hydropower, agriculture, and cultural aspects. Many studies overlapped in two or more of these categories. Here, we reference only a limited, representative sample of publications analyzed in the research.

\section{Impacts}

\section{Socioeconomic Impacts}

Research suggests that glacier runoff variability will generate significant direct and indirect socioeconomic impacts. Community livelihoods in rural mountain areas can be vulnerable to smallscale environmental changes due to the interdependence among water, biodiversity, and livelihoods (Chaudhary et al. 2011; Sherpa 2014; Konchar et al. 2015). Glacier runoff variability affects aspects of local livelihoods: livestock production, irrigated agriculture, tourism income, social conflicts, and political struggles for power over water allocation practices (Mark et al. 2010; Bury et al. 2011; French, Barandiaran, and Rampini 2015).

Changes in glacier runoff are likely to affect urban water supplies in some regions. Vergara et al. (2007) reported that reduced glacier runoff will influence La Paz and El Alto, Bolivia, where 2.3 million residents receive 30 to 40 percent of their potable water from Cordillera Real glaciers. Studies suggest future policy implications of glacier runoff variability in Bogota (Lampis 2013), and Ioris (2012) analyzed the uneven distribution of water in Lima's urban areas. Changes to glacier runoff might also affect mountain tourism, although research on the topic remains limited (Rhoades, Rios, and Ochoa 2008; Bury et al. 2011). As climate change affects glaciers, local residents could see changes to tourism assets and natural resources (Becken, Lama, and Espiner 2013). Amidst insecurities about glacier runoff variability, increased tourism can escalate water use and exacerbate water competition among locals and tourists (Nyaupane and Chhetri 2009; G. McDowell et al. 2013). Tourism in the Alps might be negatively affected as glacial runoff decreases, influencing both the appearance of the landscape and the associated tourism activities (Beniston 2012).

Water quality is also of critical importance to human livelihoods in glacier-fed watersheds. Glacier retreat can warm downstream water (Mantua, Tohver, and Hamlet 2010; Pelto 2011), with potential implications for fish populations that societies depend on for food security, fishing markets, and cultural aspects (Lackey 2000; Grah and Beaulieu 2013). Mining (Bury 2015) and changes in sediment load resulting from increased glacier melting (Riedel et al. 2015) can both affect water quality, which could be exacerbated by glacier shrinkage and declining runoff.

Assertions about the impacts of glacier runoff variability often lack evidence to substantiate claims, even though some studies identify multiple drivers of socioeconomic changes, such as weather extremes and changing precipitation regimes (Chaudhary et al. 2011; G. McDowell et al. 2013; Sherpa 2014). Näusser, Schmidt, and Dame (2012) and Sherpa (2014) illustrated that the influence 
of climate change, glacier shrinkage, and runoff variability on local people is not always distinguished from social, political, economic, and infrastructural inequities. For human migration along glacierfed waterways, evidence points less to issues of water supplies than to a range of other societal factors (Wrathall et al. 2014; Raoul 2015), which is consistent with the environmental migration literature that identifies multiple drivers of migration (e.g., Black et al. 2011).

\section{Hydropower}

Research on glacier runoff indicates diverse effects on the generation of hydroelectricity (Terrier et al. 2011; Bavay, Gr€unewald, and Lehning 2013; Beniston and Stoffel 2014). Glacier runoff variability in the greater Himalayan region, for instance, will likely have farreaching effects on hydropower, water storage, dry season flows, and related geopolitical and economic concerns (Qureshi 2011; Tiwari and Joshi 2012; Molden et al. 2014). Impacts could be particularly potent in regions dependent on hydropower such as Nepal and the Andes, in areas without access to other energy sources, and in countries diversifying energy sources for economic productivity or pursuing sustainable energy (Gardarsson and Eliasson 2006; Einarsson and Jonsson 2010; Bliss, Hock, and Radic 2014). In the Alps, however, studies point to varying outcomes. Terrier et al. (2011) suggested that there will be higher summer water volume and more storage capacity for energy production as glaciers shrink. Schaefli, Hingray, and Musy (2007) and Beniston and Stoffel (2014), on the other hand, indicated a likely decrease in hydropower production due to decreased glacier runoff. Such discrepancies can emerge due to regional variation or from timescales studied. Short-term runoff from shrinking glaciers will often increase, whereas a reduction in runoff occurs below larger glaciers or more glacierized basins on longterm scales. Impacts of glacier runoff variation on hydropower needs further documentation, and societies might not be as negatively affected as commonly asserted, especially in the near future (Mark et al. 2015).

Predictions of future hydroelectric impacts have limitations. For example, Vergara et al. (2007) estimated that glacier retreat will reduce Perus Can on del Pato hydropower output. Although this study calculates economic losses and the reduction of gigawatt hours produced in glacier-fed rivers, it does not analyze the dynamic societal factors that influence hydropower generation or energy distribution, usage, and costs. Yet tensions over hydroelectric water management are affected by sociopolitical conflicts, water competition, new water technologies, and economic development (Carey, French, and O'Brien 2012; Lynch 2012; Bury et al. 2013). Further, reservoir construction and management to compensate for glacier runoff reduction can also affect hydropower generation and society more broadly (Rasmussen 2016).

\section{Irrigation, Agriculture, and Food Security}

Research on glacier runoff often argues that glacier loss will reduce irrigation water, diminish agricultural productivity, and threaten food security in glacier-fed watersheds. In the Oregon Cascades, glacier meltwater contributions to stream flow are negligible in the lower Hood River watershed but comprise 41 to 73 percent of the upper watershed flow (Nolin et al. 2010), thus suggesting potential impacts on irrigation and agriculture. Quantitative studies in the greater Himalayan region estimate that food security for 4.5 percent of the population living in the 
Brahmaputra, Indus, water availability due to the effects of climate change on glaciers and snowmelt (Immerzeel, van Beek, and Bierkens 2010). As glacier and snow meltwater account for approximately 60 percent of upper Indus River stream flow, glacier retreat will likely generate economic and food losses for Pakistan's agriculture (Akhtar, Ahmad, and Booij 2008; Immerzeel, van Beek, and Bierkens 2010). In Peru's Santa River basin, up to 66 percent of dry season flow consists of glacier runoff, which provides most of the water for the largescale Chavimochic irrigation and agriculture project (Mark et al. 2010; Bury et al. 2013; Carey et al. 2014). Diminishing glacier runoff is likely to affect subsistence agriculture and produce water stress elsewhere in the Andes (Young and Lipton 2006; J. Z. McDowell and Hess 2012). Although highland pastoralists might experience initial benefits from increased runoff, studies claim that water stress will increase in the future with climatic uncertainty (Postigo, Young, and Crews 2008; Lopez-i-Gelats et al. 2015).

Many runoff and agriculture studies highlight factors intersecting with glacier hydrology such as changing precipitation, drying water sources, and warming weather (Chaudhary et al. 2011; J. Z. McDowell and Hess 2012). In Cotacachi, Ecuador, researchers suggest that glacier loss has heightened competition for irrigation water, but they note that precipitation, government policies, water management practices, and the social organization of water also affect agriculture and irrigation practices (Rhoades, Rios, and Ochoa 2008; Skarbø and VanderMolen 2014). In Bolivia, agriculture is influenced by factors beyond glaciers or water supply, including patterns of production, household assets, and institutional arrangements (J. Z. McDowell and Hess 2012). Other studies suggest an impact of diminishing glacier runoff on agriculture but do not differentiate among the various processes affecting food production, such as crops planted, local knowledge, or cultural influences (Bavay, Gr€unewald, and Lehning 2013; Beniston and Stoffel 2014).

In some cases, research reveals perceived and observed impacts of diminished glacier runoff. In northern India, residents report crop loss, decline in crop productivity, and reduced livestock productivity, as well as depletion of wells and groundwater sources, cultivable land, forest resources, and soil fertility (Bhadwal et al. 2013). In Peru's Cordillera Blanca, household studies in the Yanamarey Valley showed that 93 percent of agriculture- and livestockdependent respondents observed decadal decreases in dry season water supplies alongside a steady decline in glacier coverage (Bury et al. 2011). Other studies in the region suggest that locals perceive vanishing glaciers to be critical for agriculture (Young and Lipton 2006; Jurt et al. 2015). Although individuals might observe retreating glaciers and note less water, they also acknowledge that the current water realities are shaped by water governance (Rasmussen 2015). Water scarcity is as much a matter of equity as it is contingent on environmental conditions (Jaeger et al. 2013).

\section{Cultural Impacts}

Mountain residents worldwide are now questioning and, in some cases, transforming their beliefs about which forces affect regional hydrology — whether global economic changes, new power (political) dynamics, or local people's behavior and culture (Paerregaard 2013; Drenkhan et al. 2015; Jurt et al. 2015). The ways in which people imagine causality shapes their responses to water scarcity, and these understandings, local knowledges, and cultural beliefs can differ markedly from scientific 
depictions of the runoff problem (Williams and Golovnev 2015). Globally, glaciers and the mountains that sustain them have spiritual and cultural value for societies, such as the sacred Khawa Karpo mountain for Tibetan Buddhists, where the upper Yangtse, upper Mekong, upper Salween, and Dulong Rivers flow through the mountains (Allison 2015). Even though few studies discuss spiritual impacts associated with glacier runoff variability, the changes to glaciers, snow, lakes, and rivers could affect spiritual beliefs and practices (Drew 2012; Salick, Byg, and Bauer 2012; Becken, Lama, and Espiner 2013; Konchar et al. 2015).

Boelens (2014) explained how social groups see glacier runoff in the Andes differently: Engineers see it as a technical issue with biophysical characteristics; nongovernmental organizations work through sociolegal frameworks; and local residents understand it through, among other ways, historical and cultural perspectives. Elsewhere in Peru, climate change and glacier runoff variability have caused some local residents to adjust spiritual relationships because they believe that their religious offerings no longer assure adequate water supplies (Paerregaard 2013), and others report that glacier and snow loss illustrates reduced power of their Apus (deities). More research is needed to discern how cultural values, narratives, discourse, and perceptions of glaciers and hydrology are changing as glaciers retreat — and how these cultural factors affect water use and management.

\section{Refining Runoff Research: Future Directions}

\section{Detection and Attribution}

Explicit detection of global environmental changes, as well as the attribution of those observed changes to particular human and environmental drivers (Stone et al. 2013), is essential for glacier runoff research to avoid simplistic assumptions about glaciers. As glaciers shrink, they initially generate more meltwater; subsequently, watersheds experience "peak water," the point after which stream flow declines (National Academy of Sciences 2012). The runoff reduction usually manifests in the dry season, so impacts would not be constant or year-round. Further, even when glacier runoff declines at the glacier terminus, other variables influence downstream hydrology such as wetlands and human land use practices.

Studies detecting glacier runoff quantities, peak water, and downstream contributions of glacier meltwater from ice to ocean are rare in the natural sciences (see Baraer et al. 2012). Researchers usually only assume that glacier runoff has declined or will decline in the near future, without adequate consideration. Many social scientists reproduce a common misunderstanding that a shrinking glacier will cause an immediate downstream water flow reduction. Yet for the greater Himalayan region, for example, Immerzeel, Pellicciotti, and Bierkens (2013) indicated that future changes in monsoon precipitation will likely compensate for glacier runoff reduction in the Indus and Ganges Rivers. Social scientists do not conduct studies to detect glacier runoff variability because it is not their focus or expertise; however, they should analyze hydrologic studies before drawing conclusions about downstream impacts.

Societal changes in glacierized watersheds are often attributed ambiguously or unconvincingly to glacier runoff variability. The role of glaciers versus human forces of change (e.g., institutional 
change, reallocation of water rights, demographic shifts, or new land and water use practices) is, in other words, often unacknowledged. Studies concluding that water scarcity is a result of glacier losswithout attention to human variables driving water competition or restricting water access - often do not attribute water variability or human impacts to specific drivers. They are thus problematic for several reasons: They are based on speculation and tangential evidence; they do not differentiate between water availability and water allocation; they lack robust consideration of stakeholder competition for water; and they fail to consider the ways in which glacial ice, snowpack, precipitation, and groundwater interact to affect stream flow throughout glacier-fed watersheds. A central challenge for glacier runoff research is to integrate the diversity of biophysical and social processes, simultaneously disentangling them to understand which forces should be addressed in water management practices.

\section{Spatial and Temporal Scales}

Research on glacier runoff variability frequently neglects explicit analysis of temporal and spatial scales, as well as recognition that scale in and of itself is socially and historically constructed (Neumann 2015; Margulies et al. 2016). Claims about water scarcity resulting from glacier retreat generally fail to identify when a reduction in glacier runoff has occurred, or will occur, and to what effect. Further, social scientists often draw conclusions about short-term or presentday human impacts of glacier runoff variability, whereas natural scientists project long-term impacts in future decades. Identifying when glacier-fed watersheds will reach peak water - that is, an explicit consideration of temporal scales and runoff regimes over time-is critical for evaluation of hydrologic risk or promotion of specific adaptation strategies.

Moreover, greater recognition of seasonally variable impacts is essential because glacier shrinkage will have the most pronounced effect during dry seasons and summers. During winters or wet seasons, precipitation markedly increases stream flow, often above what surrounding societies use. Studies of glacier runoff variability must thus identify when the downstream effects are most potent - and how specific water demands such as crops grown, annual timing of tourism cycles, and even time of day for hydroelectricity generation shape watershed hydrology over different timescales.

More place-based studies are also needed to understand diverse hydrologic processes and human water use dynamics across a range of watersheds, mountain ranges, countries, and cultures. Gender relations, ethnic and political inequities, community-level adaptations, spiritual relations with glaciers, access to alternative water sources, and differences in local knowledge vary from one region to another (Drew 2012; Salick, Byg, and Bauer 2012; Becken, Lama, and Espiner 2013; Gagne, Rasmussen, and Orlove 2014; Rasmussen 2015; Williams and Golovnev 2015). Impacts cannot be homogenized or universalized (scaled up) even when studies show consistent glacier shrinkage across mountain ranges. Careful citation practices can help to avoid cross-regional application of claims that have not been validated. 


\section{Transdisciplinarity and Redefining the Runoff Problem}

Transdisciplinary research on water in glacierized basins is essential but must be approached carefully. Transdisciplinarity consists of interaction and collaboration across academic disciplines and also the integration and acceptance of a diverse range of knowledges, including indigenous knowledge, women's voices, local farmers' observations, and other stakeholder knowledge alongside the natural sciences (Wainwright 2010; Klenk and Meehan 2015; Carey et al. 2016). In transdisciplinary research on glacier runoff, the natural sciences and social sciences should work in "conversation" with each other — on equal footing — to detect glacier runoff variability and attribute human impacts to social-ecological drivers. Bridge building across disciplines and between researchers and nonacademic stakeholders - without one subsuming or appropriating the other-is crucial (Lave 2015).

Transdisciplinary collaboration is not enough, though, and we argue that the entire glacier runoff problem needs to be redefined - potentially in ways that transcend academic disciplinary structures (Wainwright 2010). Currently, most studies construct the problem as a glacier, water, and climate change issue. Ultimately, though, water scarcity is a socioeconomic issue (Jaeger et al. 2013). Human beings determine how much water to use and how (and to whom) it gets distributed. The glacier runoff problem needs to undergo a transformation in conceptualization, discourse, narratives - and research. We need to investigate questions of glacier runoff impacts through approaches that link biophysical and human systems, placing local livelihoods within a context of multiple forces influencing water availability and use, from changing precipitation patterns and glacier runoff rates to government policies, race relations, inequality, spirituality, ethics, and poverty (Drew 2012; Salick, Byg, and Bauer 2012; Bury et al. 2013; Carey et al. 2014; Gagne, Rasmussen, and Orlove 2014; Allison 2015).

\section{Conclusions}

Although this article addresses glacier recession and mountain hydrology specifically, it offers insights for human and physical geographers more broadly. It argues for the critical importance of detection and attribution of climate change impacts across all disciplines, topics, and world regions. The glacier case also demonstrates why careful analysis of spatial and temporal scales is vital. Additionally, the article challenges a fundamental paradigm driving much of today's glacier runoff research: that shrinking glaciers lead inevitably and immediately to water scarcity for societies - an underlying assumption that hinges on environmental determinism. Glacier (and other) research must avoid such generalizations, speculative assertions, and apocalyptic claims that lack supporting evidence. The article also reinforces the need for more social science and humanities voices in global environmental change research. The dynamic interactions between water supply and water management justify transdisciplinary collaborations, which are lacking despite decades of calls for more coupled natural-human systems research. The need to reorient glacier runoff scholarship around human dynamics - as previously done with natural disaster and environmental migration scholarship — is acute. Yet folding social sciences and humanities into the natural sciences is simply not enough when it comes to the lives and livelihoods of people living in the world's mountains. 
Hydrologic problems in glacierized basins cannot be resolved, water cannot be equitably distributed, hazard risk reduction cannot occur, and effective climate change adaptation will not occur without the integrated glacier runoff approach we are proposing for mountain regions.

\section{Funding}

Mark Carey's work is supported by the U.S. National Science Foundation under Grant \#1253779. M Jackson's work is supported by a U.S. Fulbright- National Science Foundation Arctic Research Grant. Anne W. Nolin's work is partially supported by the U.S. National Science Foundation under Grant \#1414106.

\section{References}

Akhtar, M., N. Ahmad, and M. J. Booij. 2008. The impact of climate change on the water resources of Hindukush-Karakorum-Himalaya region under different glacier coverage scenarios. Journal of Hydrology 355:148- 63.

Allison, E. A. 2015. The spiritual significance of glaciers in an age of climate change. WIREs Climate Change 6 (5): 493-508.

Baraer, M., B. G. Mark, J. McKenzie, T. Condom, J. Bury, K. I. Huh, C. Portocarrero, J. Gomez, and S. Rathay. 2012. Glacier recession and water resources in Peru's Cordillera Blanca. Journal of Glaciology 58 (207): 134-50.

Bavay, M., T. Gr€unewald, and M. Lehning. 2013. Response of snow cover and runoff to climate change in high Alpine catchments of Eastern Switzerland. Advances in Water Resources 55:4-16.

Becken, S., A. K. Lama, and S. Espiner. 2013. The cultural context of climate change impacts: Perceptions among community members in the Annapurna Conservation Area, Nepal. Environmental Development 8:22-37.

Beniston, M. 2012. Impacts of climatic change on water and associated economic activities in the Swiss Alps. Journal of Hydrology 412-413:291-96.

Beniston, M., and M. Stoffel. 2014. Assessing the impacts of climatic change on mountain water resources. Science of the Total Environment 493:1129-37.

Bhadwal, S., A. Groot, S. Balakrishnan, S. Nair, S. Ghosh, G. Lingaraj, C. Terwisscha van Scheltinga, A. Bhave, and C. Siderius. 2013. Adaptation to changing water resource availability in northern India with respect to Himalayan glacier retreat and changing monsoons using participatory approaches. Science of the Total Environment 468-469:S152-S161.

Black, R., W. N. Adger, N. W. Arnell, S. Dercon, A. Geddes, and D. Thomas. 2011. The effect of environmental change on human migration. Global Environmental Change 21 (Suppl. 1): 3-11.

Bliss, A., R. Hock, and V. Radic. 2014. Global response of glacier runoff to twenty-first century climate change. Journal of Geophysical Research: Earth Surface 119 (4): 717-30. 
Boelens, R. 2014. Cultural politics and the hydrosocial cycle: Water, power and identity in the Andean highlands. Geoforum 57:234-47.

Bury, J. 2015. The frozen frontier: The extractives super cycle in a time of glacier recession. In The high-mountain cryosphere, ed. C. Huggel, M. Carey, J. Clague, and A. Kääb, 71-89. Cambridge, UK: Cambridge University Press.

Bury, J., B. G. Mark, M. Carey, K. Young, J. McKenzie, M. Baraer, A. French, and M. Polk. 2013. New geographies of water and climate change in Peru: Coupled natural and social transformations in the Santa River watershed. Annals of the Association of American Geographers 103 (2): 363-74.

Bury, J., B. G. Mark, J. McKenzie, A. French, M. Baraer, K. In Huh, M. Zapata Luyo, and R. J. Gomez Lopez. 2011. Glacier recession and human vulnerability in the Yanamarey watershed of the Cordillera Blanca, Peru. Climatic Change 105 (1-2): 179-206.

Carey, M., M. Baraer, B. G. Mark, A. French, J. Bury, K. R. Young, and J. M. McKenzie. 2014. Toward hydro-social modeling: Merging human variables and the social sciences with climate-glacier runoff models (Santa River, Peru). Journal of Hydrology 518:60-70.

Carey, M., A. French, and E. O’Brien. 2012. Unintended effects of technology on climate change adaptation: An historical analysis of water conflicts below Andean glaciers. Journal of Historical Geography 38 (2): 181-91.

Carey, M., M Jackson, A. Antonello, and J. Rushing. 2016. Glaciers, gender, and science: A feminist glaciology framework for global environmental change research. Progress in Human Geography. Advance online publication. doi: 10.1177/0309132515623368

Chaudhary, P., S. Rai, S. Wangdi, A. Mao, N. Rehman, S. Chettri, and K. S. Bawa. 2011. Consistency of local perceptions of climate change in the Kangchenjunga Himalaya landscape. Current Science 101 (4): 504-13.

Drenkhan, F., M. Carey, C. Huggel, J. Seidel, and M. T. Ore. 2015. The changing water cycle: Climatic and socioeconomic drivers of water-related changes in the Andes of Peru. WIREs Water 2 (6): 715-33.

Drew, G. 2012. A retreating goddess? Conflicting perceptions of ecological change near the GangotriGaumukh glacier. Journal for the Study of Religion, Nature and Culture 6 (3): 344-62.

Einarsson, B., and S. Jonsson. 2010. The effect of climate change on runoff from two watersheds in Iceland. Paper presented at the Conference on Future Climate and Renewable Energy: Impacts, Risks and Adaptation, Oslo, Norway.

Folke, C. 2006. Resilience: The emergence of a perspective for social-ecological systems analyses. Global Environmental Change 16:253-67. 
French, A., J. Barandiaran, and C. Rampini. 2015. Contextualizing conflict: Vital waters and competing values in glaciated environments. In The high-mountain cryosphere: Environmental changes and human risks, ed. C. Huggel, M. Carey, J. Clague, and A. K€a€ab, 315-36. Cambridge, UK: Cambridge University Press.

Gagne, K., M. B. Rasmussen, and B. Orlove. 2014. Glaciers and society: Attributions, perceptions, and valuations. WIREs Climate Change 5:793-808.

Gardarsson, S., and J. Eliasson. 2006. Influence of climate warming on Halslon Reservoir sediment filling. Nordic Hydrology 37 (3): 235-45.

Grah, O., and J. Beaulieu. 2013. The effect of climate change on glacier ablation and baseflow support in the Nooksack River basin and implications on Pacific salmonid species protection and recovery. Climatic Change 120:657-70.

Hulme, M. 2011. Reducing the future to climate: A story of climate determinism and reductionism. Osiris 26:245-66.

Immerzeel, W. W., F. Pellicciotti, and M. F. P. Bierkens. 2013. Rising river flows throughout the twenty-first century in two Himalayan glacierized watersheds. Nature Geoscience 6:742-45.

Immerzeel, W. W., L. P. H. van Beek, and M. F. P. Bierkens. 2010. Climate change will affect the Asian water towers. Science 328:1382-85.

Intergovernmental Panel on Climate Change. 2014. Climate change 2014: Impacts, adaptation, and vulnerability. Part A: Global and sectoral aspects. Contribution of Working Group II to the Fifth Assessment Report of the Intergovernmental Panel on Climate Change. New York: Cambridge University Press.

Ioris, A. A. R. 2012. The geography of multiple scarcities: Urban development and water problems in Lima, Peru. Geoforum 43 (3): 612-22.

Jaeger, W. K., A. J. Plantinga, H. Chang, K. Dello, G. Grant, D. Hulse, J. J. McDonnell, et al. 2013. Toward a formal definition of water scarcity in natural-human systems. Water Resources Research 49 (7): 4506-17.

Jurt, C., M. D. Burga, L. Vicuna, C. Huggel, and B. Orlove. 2015. Local perceptions in climate change debates: Insights from case studies in the Alps and the Andes. Climatic Change 133 (3): $511-$ 23.

Klenk, N., and K. Meehan. 2015. Climate change and transdisciplinary science: Problematizing the integration imperative. Environmental Science and Policy 54:160-67.

Konchar, K. M., B. Staver, J. Salick, A. Chapagain, L. Joshi, S. Karki, S. Lo, A. Paudel, P. Subedi, and S. K. Ghimire. 2015. Adapting in the shadow of Annapurna: A climate tipping point. Journal of Ethnobiology 35 (3): 449-71. 
Lackey, R. 2000. Restoring wild salmon to the Pacific Northwest: Chasing an illusion? In What we don't know about Pacific Northwest fish runs: An inquiry into decisionmaking, ed. P. Koss and M. Katz, 91-143. Portland, OR: Portland State University.

Lampis, A. 2013. Cities and climate change challenges: Institutions, policy style and adaptation capacity in Bogota. International Journal of Urban and Regional Research 37 (6): 1879-1901.

Lave, R. 2015. Exploring the proper relation between phyical and human geography: Early work by John E. Thornes and Ron Johnston. Progress in Physical Geography 39 (5): 687-90.

Lopez-i-Gelats, F., J. L. Contreras Paco, R. Huilcas Huayra, O. D. Siguas Robles, E. C. Quispe Pena, and J. Bartolome Filella. 2015. Adaptation strategies of Andean pastoralist households to both climate and non-climate changes. Human Ecology 43 (2): 267-82.

Lynch, B. D. 2012. Vulnerabilities, competition and rights in a context of climate change: Toward equitable water governance in Peru's Rio Santa Valley. Global Environmental Change 22 (2): $364-$ 73.

Mantua, N., I. Tohver, and A. Hamlet. 2010. Climate change impacts on streamflow extremes and summertime stream temperature and their possible consequences for freshwater salmon habitat in Washington State. Climatic Change 102 (1-2): 187-223.

Margulies, J. D., N. R. Magliocca, M. D. Schmill, and E. C. Ellis. 2016. Ambiguous geographies: Connecting case study knowledge with global change science. Annals of the Association of American Geographers 106 (3): 572-96.

Mark, B. G., M. Baraer, A. Fernandez, W. W. Immerzeel, R. D. Moore, and R. Weingartner. 2015. Glaciers as water resources. In The high-mountain cryosphere: Changes and risks, ed. C. Huggel, M. Carey, J. J. Clague, and A. Kääb, 184-203. Cambridge, UK: Cambridge University Press.

Mark, B. G., J. Bury, J. McKenzie, A. French, and M. Baraer. 2010. Climate change and tropical Andean glacier recession: Evaluating hydrologic changes and livelihood vulnerability in the Cordillera Blanca, Peru. Annals of the Association of American Geographers 100 (4): 794-805.

McDowell, G., J. D. Ford, B. Lehner, L. Berrang-Ford, and A. Sherpa. 2013. Climate-related hydrological change and human vulnerability in remote mountain regions: A case study from Khumbu, Nepal. Regional Environmental Change 13 (2): 299-310.

McDowell, J. Z., and J. J. Hess. 2012. Accessing adaptation: Multiple stressors on livelihoods in the Bolivian highlands under a changing climate. Global Environmental Change 22 (2): 342-52.

Molden, D. J., R. A. Vaidya, A. B. Shrestha, G. Rasul, and M. S. Shrestha. 2014. Water infrastructure for the Hindu Kush Himalayas. International Journal of Water Resources Development 30 (1): 6077. 
National Academy of Sciences. 2012. Himalayan glaciers: Climate change, water resources, and water security. Washington, DC: National Academy of Sciences.

Neumann, R. P. 2015. Political ecology of scale. In The international handbook of political ecology, ed. R. L. Bryant, 475-86. Northampton, MA: Edward Elgar.

Nolin, A. W., J. Phillippe, A. Jefferson, and S. L. Lewis. 2010. Present-day and future contributions of glacier runoff to summertime flows in a Pacific Northwest watershed: Implications for water resources. Water Resources Research 46:W12509.

Näusser, M., S. Schmidt, and J. Dame. 2012. Irrigation and development in the Upper Indus Basin. Mountain Research and Development 32 (1): 51-61.

Nyaupane, G. P., and N. Chhetri. 2009. Vulnerability to climate change of nature-based tourism in the Nepalese Himalayas. Tourism Geographies 11 (1): 95-119.

Paerregaard, K. 2013. Bare rocks and fallen angels: Environmental change, climate perceptions and ritual practices in the Peruvian Andes. Religions 4 (2): 290-305.

Pelto, M. S. 2011. Skykomish River, Washington: Impact of ongoing glacier retreat on streamflow. Hydrological Processes 25 (21): 3356-63.

Petticrew, M., and H. Roberts. 2006. Systematic reviews in the social sciences: A practical guide. Malden, MA: Blackwell.

Postigo, J. C., K. R. Young, and K. A. Crews. 2008. Change and continuity in a pastoralist community in the high Peruvian Andes. Human Ecology 36 (4): 535-51.

Qureshi, A. S. 2011. Water management in the Indus basin in Pakistan: Challenges and opportunities. Mountain Research and Development 31 (3): 252-60.

Raoul, K. 2015. Can glacial retreat lead to migration? A critical discussion of the impact of glacier shrinkage upon population mobility in the Bolivian Andes. Population and Environment 36 (4): 480 96.

Rasmussen, M. B. 2015. Andean waterways: Resource politics in highland Peru. Seattle: University of Washington Press.

2016. Water futures: Contention in the construction of productive infrastructure in the Peruvian highland. Anthropologica 58 (2): 211-26.

Rhoades, R. E., X. Z. Rios, and J. A. Ochoa. 2008. Mama Cotacachi: History, local perceptions, and social impacts of climate change and glacier retreat in the Ecuadorian Andes. In Darkening peaks: Glacier retreat, science, and society, ed. B. Orlove, E. Wiegandt, and B. H. Luckman, 216-25. Berkeley and Los Angeles: University of California Press. 
Riedel, J. L., S. Wilson, W. Baccus, M. Larrabee, T. Fudge, and A. Fountain. 2015. Glacier status and contribution to streamflow in the Olympic Mountains, Washington, USA. Journal of Glaciology 61 (225): 8-16.

Rodela, R. 2011. Social learning and natural resource management: The emergence of three research perspectives. Ecology and Society 16 (4): 30.

Salick, J., A. Byg, and K. Bauer. 2012. Contemporary Tibetan cosmology of climate change. Journal for the Study of Religion, Nature \& Culture 6 (4): 447-76.

Schaefli, B., B. Hingray, and A. Musy. 2007. Climate change and hydropower production in the Swiss Alps: Quantification of potential impacts and related modelling uncertainties. Hydrology and Earth System Sciences Discussions 11 (3): 1191-1205.

Sherpa, P. 2014. Climate change, perceptions, and social heterogeneity in Pharak, Mount Everest region of Nepal. Human Organization 73 (2): 153-61.

Sivapalan, M., H. H. G. Savenije, and G. Bl€oschl. 2012. Socio-hydrology: A new science of people and water. Hydrological Processes 26 (8): 1270-76.

Skarbø, K., and K. VanderMolen. 2014. Irrigation access and vulnerability to climate-induced hydrological change in the Ecuadorian Andes. Culture, Agriculture, Food and Environment 36 (1): $28-44$.

Stone, D., M. Auffhammer, M. Carey, G. Hansen, C. Huggel, W. Cramer, D. Lobell, M. Ulf, A. Solow, L. Tibig, and G. Yohe. 2013. The challenge to detect and attribute effects of climate change on human and natural systems. Climatic Change 121 (2): 381-95.

Swyngedouw, E. 2009. The political economy and political ecology of the hydro-social cycle. Journal of Contemporary Water Research and Education 142: 56-60.

2010. Apocalypse forever? Post-political populism and the spectre of climate change. Theory Culture \& Society 27 (2-3): 213-32.

Terrier, S., F. Jordan, A. Schleiss, W. Haeberli, C. Huggel, and M. K€unzler. 2011. Optimized and adapted hydropower management considering glacier shrinkage scenarios in the Swiss Alps. In Dams and reservoirs under changing challenges, ed. A. Schleiss and R. M. Boes, 497-508. New York: CRC Press, Taylor \& Francis Group.

Tiwari, P. C., and B. Joshi. 2012. Environmental changes and sustainable development of water resources in the Himalayan headwaters of India. Water Resources Management 26 (4): 883-907.

Vergara, W., A. Deeb, A. M. Valencia, R. S. Bradley, B. Francou, A. Zarzar, A. Gr€unwaldt, and S. Haeussling. 2007. Economic impacts of rapid glacier retreat in the Andes. EOS, Transactions American Geophysical Union 88 (25): 261-68. 
Wainwright, J. 2010. Climate change, capitalism, and the challenge of transdisciplinarity. Annals of the Association of American Geographers 100 (4): 983-91.

Williams, C., and I. Golovnev. 2015. Pamiri women and the melting glaciers of Tajikistan. In A political ecology of women, water and global environmental change, ed. S. Buechler and A.-M. S. Hanson, 206-23. London and New York: Routledge.

Wong, E. 2015. Chinese glacier's retreat signals trouble for Asian water supply. New York Times 8 December 2015. http://www.nytimes.com/2015/12/09/world/asia/chineseglaciers-retreat-signalstrouble-for-asian-water-supply. html?_rD0 (last accessed 2 July 2016).

Wrathall, D. J., J. Bury, M. Carey, B. Mark, J. McKenzie, K. Young, M. Baraer, A. French, and C. Rampini. 2014. Migration amidst climate rigidity traps: Resource politics and social-ecological possibilism in Honduras and Peru. Annals of the Association of American Geographers 104 (2): 292304.

Young, K., and J. Lipton. 2006. Adaptive governance and climate change in the tropical highlands of western South America. Climatic Change 78 (1): 63- 102.

MARK CAREY is an Associate Professor of History in the Robert D. Clark Honors College and an Associate Professor of Environmental Studies, both at the University of Oregon, Eugene, OR 97403. E-mail: carey@uoregon.edu. He runs the Glacier Lab for the study of ice and society, and his research focuses on glacier-society dynamics, history of glaciological knowledge, climate change, water governance, and natural disasters, particularly in the Andes and Arctic.

OLIVIA C. MOLDEN is a Doctoral Student in Geography at the University of Oregon, Eugene, OR 97403. E-mail: omolden@uoregon.edu. She currently studies the cultural politics of water and infrastructure development in the Kathmandu Valley, Nepal.

MATTIAS BORG RASMUSSEN is an Assistant Professor in the Department of Food and Resource Economics, University of Copenhagen, Rolighedsvej 25, 1958 Frederiksberg, Denmark. E-mail: mbr@ifro.ku.dk. An anthropologist by training, he has worked extensively in Peru on matters of local politics, resource management, and processes of exclusion and inclusion. His current research focuses on dynamics of territorialities, modes of governance, and articulations of citizenship in the context of climate change and conservation landscapes.

M JACKSON is a PhD Candidate in Geography at the University of Oregon, Eugene, OR 97403. Email: jerilynn@uoregon.edu. Her research focuses on human-glacier relationships in the Arctic, with a specific emphasis on local narratives of glacier change in Iceland.

ANNE W. NOLIN is a Professor in the College of Earth, Ocean, and Atmospheric Sciences, Oregon State University, Corvallis, OR 97331. E-mail: nolina@oregonstate.edu. She leads the Mountain Hydroclimatology Research Group, and her research focuses on snow and ice in the climate system and mountains as social-ecological systems. 
BRYAN G. MARK is a Professor in the Geography Department and Research Scientist at the Byrd Polar and Climate Research Center (BPCRC), The Ohio State University, Columbus, OH 43210. Email: mark.9@osu.edu. He leads a research group at BPCRC entitled Glacier Environmental Change, and his interests include glaciers, climate change, paleoclimatology, hydrology, and coupled human and natural systems, focused mostly in mountain regions. 